\title{
Free flaps in Surgical Dermatology. Comparison between fasciocutaneous and myocutaneous free flaps in facial reconstructions
}

\author{
Retalhos livres em dermatologia cirúrgica. Comparação entre os retallhos livres \\ fasciocutâneos e miocutâneos nas reconstruções faciais
}

\author{
Francisco Miguel Camacho-Martínez ${ }^{1}$ \\ Clara Salazar ${ }^{3}$ \\ David Moreno5
}

\author{
Angel Rollón ${ }^{2}$ \\ Elena M. Rodríguez-Rey ${ }^{4}$
}

\begin{abstract}
BACKGROUND: Dermatologic surgeons routinely harvest pedicled flaps at distance with an axial or random pattern to repair facial defects. These types of skin flaps are time-consuming and have high economic, social and personal costs. These drawbacks could be avoided with the introduction of a single-step transfer of free flaps to the recipient site, with microvascular anastomosis.

OвJестіvE: To demonstrate that better results are obtained with myocutaneous or fasciocutaneous free flaps and which one is more suitable in surgical dermatology.

Material AND Methods: We selected two patients of opposite sexes and similar ages who had undergone Mohs surgery to remove recurrent malignant tumors that were located in the upper cheek bordering the zygomatic zone. The woman was treated with a fasciocutaneous radial free flap and the man with a rectus abdominis free flap.

RESULTS: Both patients had excellent immediate postoperative outcomes. Complications observed in the male patient were related to a previous pulmonary alteration. The fasciocutaneous radial free flap reconstruction was easier to perform than the rectus abdominis free flap; nevertheless, the radial free flap is very thin and, although the palmaris longus tendon is used, it does not yield enough volume, requiring later use of implants. In contrast, the rectus abdominis free flap transfers a wide flap with enough fat tissue to expand in the future. As for the cosmetic results regarding the donor site, the rectus abdominis free flap produces better-looking scars, since secondary defects of the palmar surface cannot be directly closed and usually require grafting - a situation that some patients do not accept. Conclusions: In surgical dermatology, each case, once the tumor has been extirpated, requires its own reconstructive technique. The radial free flap is suitable for thin patients who are willing to cover their arm with a shirt. The rectus abdominis free flap is best suited for obese patients with deep and voluminous defects, although it is necessary to dislocate the navel from its original position.
\end{abstract}

Keywords: Mohs surgery; Muscle development; Surgical flaps

Resumo: FundAMENTOS: Os cirurgiões dermatológicos habitualmente realizam retalhos pediculados cutâneos à distância, de padrão axial ou ao acaso, para reparar os defeitos faciais. Estes tipos de retalhos cutâneos requerem muito tempo para realizar-se e têm elevadas despesas econômicas, sociais e pessoais. Com a introdução da transferência em uma única etapa de retalhos livres ao local receptor, com anastomose microvascular, estes inconvenientes poderiam ser evitados.

OвJETIVo: Demonstrar que se obtêm melhores resultados com retalhos livres fasciocutâneos ou miocutâneos e qual deles é mais adequado em Dermatologia cirúrgica.

Material E MÉTODos: Selecionamos dois pacientes, de sexos diferentes e idades similares, que haviam sido tratados com cirurgia de Mohs, para eliminar os tumores malignos recidivantes que se localizavam na parte superior das bochechas contatando com a zona zigomática. A mulher foi tratada com um retalho livre fasciocutâneo radial e o homem com um retalho livre do músculo reto do abdômen. RESUlTADOS: Ambos os pacientes tiveram excelentes períodos pós-operatórios imediatos. As complicações observadas no homem foram relacionadas a uma alteração pulmonar prévia. O retalho fasciocutâneo radial livre foi mais fácil de realizar do que o do reto do abdômen; não obstante, o retalho livre radial é muito fino e, embora lhe seja incluído tendão do palmar, não proporciona suficiente volume razão pela qual requer a introdução posterior de implantes. Em contrapartida, o retalho livre do reto do abdômen transfere um largo retalho que tem suficiente tecido grasso para poder engordar no futuro. Quanto aos resultados estéticos da zona doadora, o retalho do reto do abdômen produz melhores cicatrizes, já que os defeitos secundários da superfície palmar do antebraço não podem ser fechados diretamente e requerem habitualmente a aplicação de um enxerto; situação que alguns pacientes não aceitam.

CONCLUSÕES: Como sempre em Dermatologia cirúrgica, cada paciente e cada tumor, uma vez extirpado, tem sua própria técnica reconstrutiva. O retalho livre radial é adequado para pacientes magros que não se incomodam de cobrir seu antebraço com a camisa. O retalho do reto do abdômen é mais adequado para pacientes obesos com defeitos profundos e voluminosos, embora seja necessário deslocar o umbigo de sua posição original.

Palavras-chave: Cirurgia de Mohs; Desenvolvimento muscular; Retalhos cirúrgicos

Recebido em 05.10.2010.

Aprovado pelo Conselho Consultivo e aceito para publicação em 01.02.2011

* Work conducted at the Department of Dermatology, Virgen Macarena University Hospital - Seville, Spain.

Financial Support: None / Suporte Financeiro: Nenbum

Conflict of Interest: None / Conflito Interesses: Nenbum

Head of the Department of Dermatology; Board Member of the International League of Dermatologic Societies; Head Professor of Dermatology, School of Medicine, Virgen Macarena University Hospital - Seville, Spain.

Head of the Service of Maxillofacial Dermatology, Virgen Macarena University Hospital - Seville, Spain.

Maxillofacial Dermatologist, Service of Dermatology, Virgen Macarena University Hospital - Seville, Spain.

Dermatologist, Department of Dermatology, Virgen Macarena University Hospital - Seville, Spain.

Dermatologist, Department of Dermatology; Head of the Unit of Dermatology, Virgen Macarena University Hospital- Seville, Spain. 


\section{INTRODUCTION}

Dermatologic surgeons reconstructed the lower face and neck with cutaneous flaps of an axial pattern, that is, those that harbor a main vessel in their axis which supports direct blood supply and therefore do not require "delays" to be transferred to the defect. Although they are commonly used as "flat flaps" they can also be "tubed", especially in cases requiring long-distance travels or those that have to be transported by a "carrier organ". The most widely used axial flat flap is the deltopectoral flap, or Backamjian flap, which uses the skin of the deltoid region with a horizontal vascular pedicle from the first four anterior perforating branches of the internal mammary artery. If the flap has to be longer to reach the zygomatic and temporal regions, it will have to be extended through the deltoid region and, in this case, the flap will have a random pattern and "delays" will be necessary. ${ }^{1,2}$ Other cutaneous axial flat flaps such as the transverse thoracoabdominal flap, groin flap and hypogastric flap are not suitable for the reconstruction of facial defects. ${ }^{3}$

To repair defects of the upper cheek, we often employed an extended deltopectoral flap with its necessary "delays" to ensure its survival. This technique is time-consuming, and therefore, costly for the patient. ${ }^{2}$ Another alternative to repair cheek defects is to use axial muscle flaps alone or in combination with a deltopectoral flap or myocutaneous axial flaps such as latissimus dorsi or pectoralis major, in order to provide a natural contour. We never use the trapezius flap to reconstruct cheek defects. The pectoralis major myocutaneous flap can be paddled to provide cheek lining as well as coverage. Although it provides excellent results, there is the disadvantage of large scars on the thorax. The latissimus dorsi myocutaneous flap has a thoracodorsal pedicle $8-12 \mathrm{~cm}$ long that allows the transfer of the flap through a tunnel or over the pectoralis major to the cheek defect providing bulk, lining and coverage. This flap has the advantage that the scar is not visible and there is no significant loss of functionality. ${ }^{4}$

However, all surgeons who have recently performed free flap transfer with microvascular anastomosis agree that this type of flap yields better results to reconstruct major defects as compared with pedicled flap. ${ }^{5}$ When we introduced in our Department the use of single-step free flap transfer with microvascular anastomosis, we began to employ different types of fasciocutaneous or myocutaneous flaps to treat large facial defects that exposed vital anatomical structures, such as vascular or neural structures.

\section{MATERIAL AND METHODS}

The objective of the study was to compare the advantages and disadvantages of fasciocutaneous and myocutaneous free flaps to repair similar defects in the upper cheeks. We selected two patients with similar cheek defects after the extirpation of a tumor: a 50year-old woman with dermatofibrosarcoma protuberans (DFSP) on her left cheek, which had been removed through Mohs micrographic surgery, and a 56-year-old man with sclerodermiform basal cell carcinoma (BCC) on his right cheek, which had also been treated with Mohs surgery.

Case 1 - old female patient who was seen at the Department of Dermatology with a retractile scar on her left cheek resulting from a surgical DFSP intervention in May 2004. Since recurrence was suspected, we performed a biopsy to confirm the presence of DFSP. Once the diagnosis was confirmed, we prepared the patient for another Mohs micrographic surgery. Three stages were necessary to confirm that the tumor had been completely extirpated. For this reason, we had to reach the adjacent fascia and peribuccal area. To repair the defect, we designed a fasciocutaneous radial forearm free flap, also known as "Chinese flap". The technique is described below.

Radial forearm free flap technique. To harvest the fasciocutaneous radial forearm free flap the patient has to be in supine position, with his forearm extended over an auxiliary table. With the use of Doppler ultrasonography, the radial artery, parallel to the cephalic vein, was located. The forearm flap had to be designed in accordance with the width and depth of the facial defect, that is, $7 \mathrm{~cm}$ wide by $10 \mathrm{~cm}$ long. The radial artery, the cephalic vein and the palmaris longus tendon were isolated in the axis of the flap (Figure 1A). Once the vascular pedicle and tendon were ligated and sectioned, the flap was transferred to the facial defect (Figure 1B), where the tendon was sutured between the coronoid apophysis and buccal commissure, and the radial artery and cephalic vein with the facial vein and artery. To ease blood flow, once microvascular anastomosis was performed, the flap was rotated 45 degrees to the right to suture the vessels in the preauricular region (Figure 2A). Lastly, the flap was sutured to deep structures with absorbable suture and to peripheral skin with silk suture (Figure 2B). Patient follow-up showed that the flap retracted within less than a year. However, the tendinous suture kept the buccal commissure in place. To counterbalance the retraction, hyaluronic acid (Restylane ${ }^{\circledR}$ ) was injected to fill the spaces with excellent results.

Case 2. A 56-year-old male patient who underwent Mohs micrographic surgery at the age of 35 due to a large sclerodermiform BCC on his right cheek that had been previously treated with X-rays in anoth- 

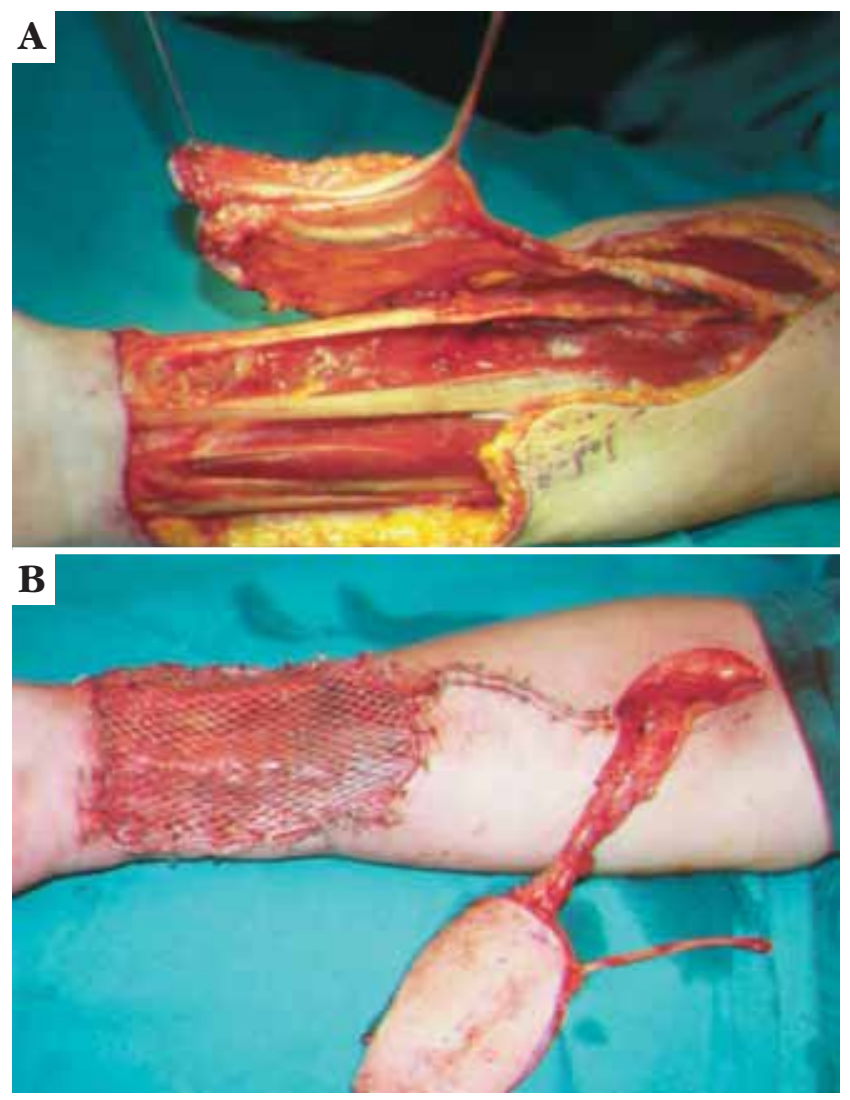

FIGURE 1: A. Radial forearm free flap is designed and havested. Its dimensions are $7 \mathrm{~cm}$ wide and $10 \mathrm{~cm}$ long, and include inside radial artery, cephalic vein, and a vascularized palmaris longus tenden. B. Paddle of the radial flap ready for transfer before the vessels are dissected and ligated

er hospital. Fifteen years later, he developed a recurrence and a new Mohs micrographic surgery was performed. It was necessary to remove the zygomatic arc, and the large defect was closed with a transposition flap starting in the neck. He was seen again six years later, and a large ulcer on his right cheek was observed. Mohs micrographic surgery was again performed but, in this case, five stages were necessary to confirm that the tumor had reached the superior ramus of the mandible. In view of this situation, we requested help from the Maxillofacial Surgery Service in our hospital, which removed the ascending mandibular ramus. The defect was closed with a rectus abdominis myocutaneous free flap. The technique is described below.

Rectus abdominis free flap technique. An oblique extended type was designed for the myocutaneous "paddle" to harbor the deep inferior epigastric artery and one or two perforators that are close to the umbilical area (Figure 3). Once the flap was designed, the skin was incised to the subjacent muscle fascia and the flap was elevated over the fascia of the external oblique and rectus abdominis muscles, from lateral to medial. To identify the lateral border of the rectus abdominis muscle, a vertical incision was made in the anterior laminae of the rectus sheath. Subsequently, it was necessary to retract the lateral border of the muscle to identify the deep inferior epigastric veins and arteries in the preperitoneal areolar tissue. Then the skin paddle of the rectus muscle fascia was carefully dissected until we could locate the two or three main perforators that we included in the flap, together with the fascia that exists around these perforators. Next, the upper border of the rectus muscle was incised and ligated, and it was then elevated and turned around to identify in its posterior surface the trajectory of the inferior epigastric vessels. Then we carefully cut and ligated the most inferior border of the rectus muscle, over the arcuate line not to damage the epigastric vessels and perforators. Next, we dissected the deep inferior epigastric vessels up to their origin in the medial surface of the external iliac artery, ligated the small collateral rami and, finally, ligated the artery and the vein the closest possible to its origin in the external iliac vein and artery vein. We then elevated the rectus abdominis myocutaneous free flap. After this, a reinforcement suture was performed to join the medial and lateral portions of the left rectus abdominis muscle, and a synthetic mesh lamina was placed over this suture. Lastly, subcutaneous absorbable sutures and non-absorbable silk sutures were done in the abdominal wall to close the donor site.

Meanwhile, another medical team was preparing the receptor recipient site for the flap transfer. After removing the ascending mandibular ramus, the facial artery and vein were prepared for microvascular anastomosis with the epigastric vessels. After vascular microanastosis is performed, in order to keep the myocutaneous paddle in its place, silk suture is used to join the cutaneous portion and the peripheral cutaneous tissues and an absorbable suture is used to join the muscular portion to the bottom cheek (Figure 4A). The patient had an episode of apnoea in the immediate postoperatory period and the distal part of the flap necrosed superficially without fistula formation. The necrotic tissue was removed and the area was grafted with excellent results (Figure $4 \mathrm{~B}$ ). However, the patient had a subsequent complication that affected his abdominal wall. This was our medical team's fault because we removed the silk stitches at day seven, believing that the reinforcement suture and synthetic mesh would withstand any tension or pressure. But a coughing fit in the immediate postoperative period led to the dehiscence of the abdominal wound. This was easily corrected with new silk suture and the use of bandages for several months. 

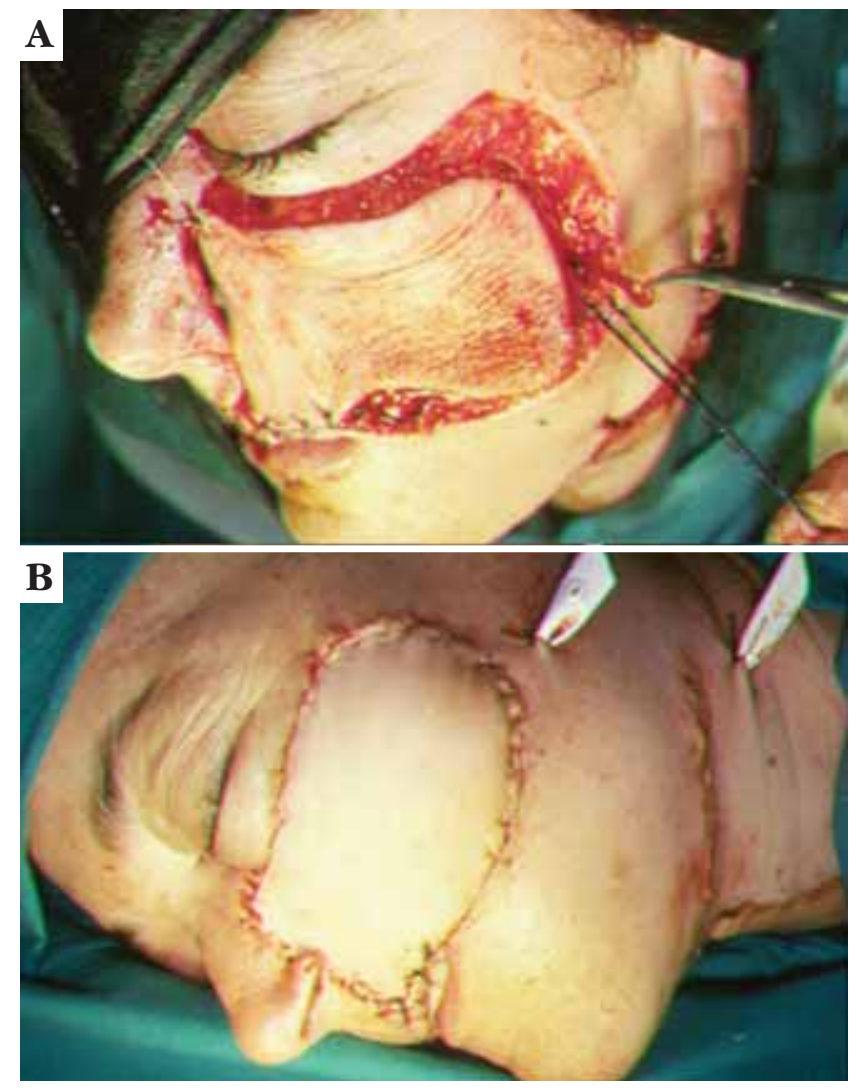

FiguRE 2: A. Microvascular anastomosis between the radial artery and cephalic vein with the facial artery and vein, B. Paddle of the radial forearm flap sutured to the left cheek defect

\section{DISCUSSION}

Most surgeons who perform reconstructive surgery, including dermatologic surgeons, agree that the best way to correct large facial defects is to use free flaps, either the fasciocutaneous radial forearm free flap or the myocutaneous rectus abdominis free flap, although both have their advantages and disadvantages. The use of the fasciocutaneous radial forearm free flap, which is harvested from the palmar surface of the forearm and whose base is in the radial artery, has been described in penile reconstruction. It is of special interest in surgical dermatology because it allows, when necessary, the transfer of skin, subcutaneous tissue, fascia covering the underlying muscles, tendons and muscles. All these tissues can be transferred with the blood supply of the radial artery and its concomitant veins, cephalic veins and sometimes the basilic vein to reconstruct head and neck defects. ${ }^{6}$ In addition, the flap should include two sensory nerves: the lateral antebrachial cutaneous nerve and a branch of the medial antebrachial cutaneous nerve. Depending on the need for tissue to cover facial defects, a flap $14-16 \mathrm{~cm}$ wide by $15-18 \mathrm{~cm}$ long can be designed. When it is necessary to replace the oral mucosa and the cheek, a "sandwich" technique can be

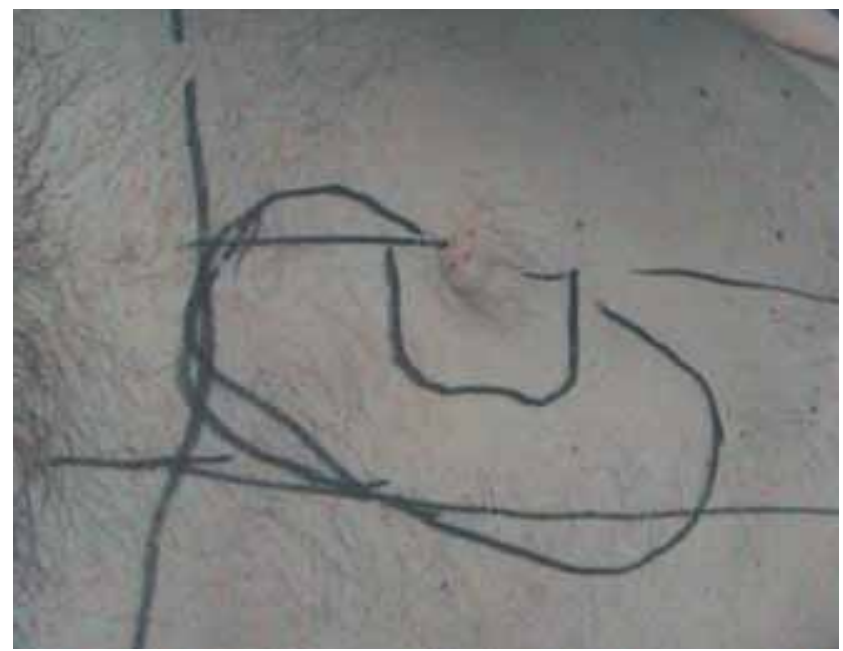

Figure 3: Free flap of the rectus abdominal oblique type, designed in the abdominal wall. The design around the navel marks the perforators

employed. ${ }^{7}$ The palmaris longus muscle can be incorporated not only to give consistency to the flap, but also to give bulk and support to the lateral portion of the lip. This flap is easy to perform and, as far as we know, has low morbidity that includes defects of the donor site. Nevertheless, some authors have reported significant morbidity such as alteration of hand and wrist function, including wrist fractures, ${ }^{8}$ aesthetic alteration of the donor site, delayed wound healing after laminar skin graft ${ }^{9,10}$ and very rarely, vascular impairment after surgery. ${ }^{11}$ It was shown, through a questionnaire, that a prior conversation with the patient explaining the technique, with its advantages and disadvantages, may reduce complaints caused by the aesthetic impact of scars in the forearm. ${ }^{6,12}$

The myocutaneous rectus abdominis free flap can be transversely (TRAM flap), vertically (VRAM flap) or obliquely designed. Although rectus abdominis flaps are often not transversal, but vertical (VRAM) or oblique, they are still known as "free TRAM flaps." This type of flap was introduced in the 80s to replace the musculocutaneous flap harvested from the lattisimus dorsi in breast reconstruction.

Initially described as vascularized pedicled flap, it was later used as "myocutaneous island flap" and finally as "free flap". We only use medial and inferior TRAM flaps and oblique flaps, since their vascular input comes from the deep inferior epigastric artery and perforators, ${ }^{13}$ whose most lateral row, which is the most important, is located less than 2.5 $\mathrm{cm}$ below the navel. ${ }^{14,15}$ The flaps can be of four types: 1.Type I or "pectoralis major flap." It is called pectoralis major because a chest-like fusiform incision is made; in addition, the fascia and muscles are often similar to the skin paddle, thus adding a lot of vol- 

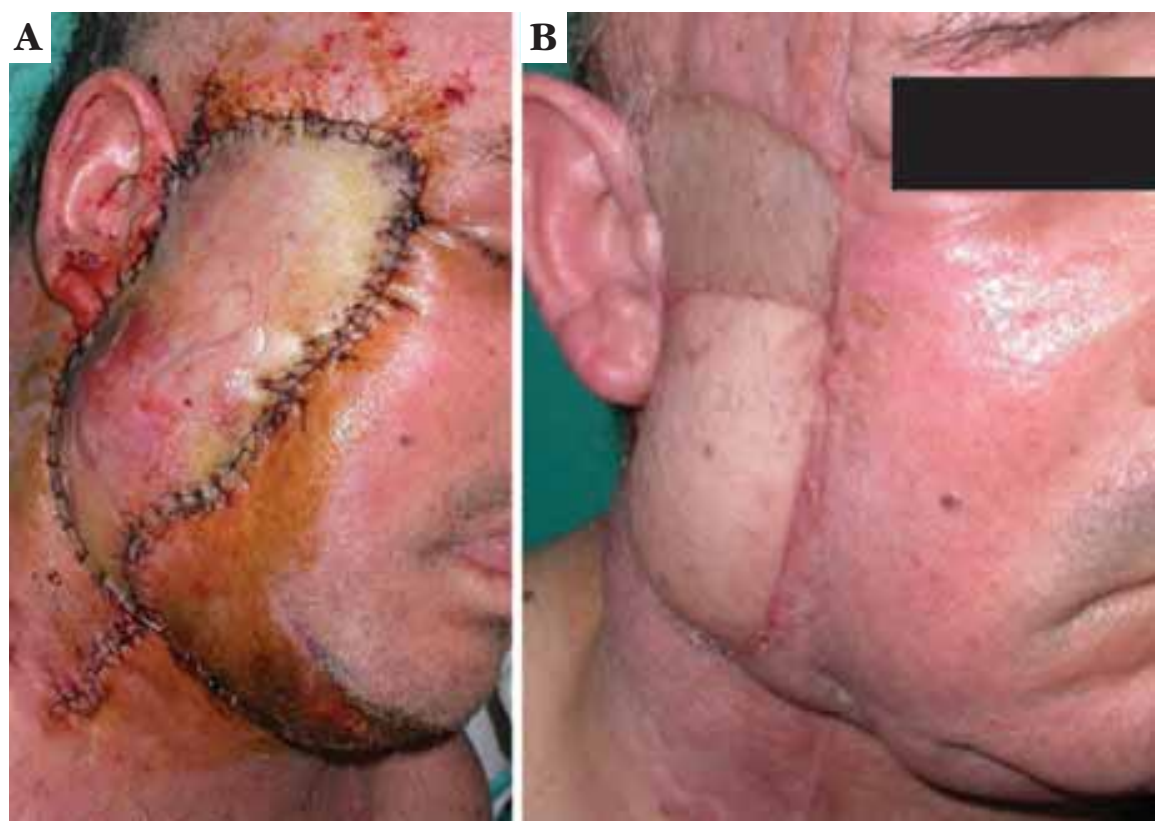

Figure 4: A. Paddle of the rectus abdominis free flap silk-sutured to the cheek defect; B. Final result after removing necrotic tissue and performing a mesh graft in the distal portion that underwent vascular damage

ume. 2. Type II or "extended" flap - so called because the skin paddle extends in various directions (vertically or obliquely) in relation to the underlying muscle and, therefore, is only ligated at the paraumbilical region. 3. Type III or "reduced muscle flap" - The muscle is reduced to the bare minimum since it is only maintained at the level of the main perforators. 4. Type IV or "thinned" flap - in this type of flap, the skin paddle is thinned by eliminating subcutaneous tissue. ${ }^{16}$ Due to arterial connections with adjacent vascular territories, there is a wide range of flap designs that include different combinations of tissues. ${ }^{17}$ Of the four types of TRAM flaps, the first two seem to be the most useful in facial reconstructions, especially extended vertical or oblique flaps.

The rectus abdominis flap can be designed and prepared quickly and easily; hence its various uses. ${ }^{16}$ Although it was first employed in breast reconstruction, ${ }^{14,18-20}$ today this is the best free flap for the complex reconstruction of the cranial base ${ }^{21}$ and other less complex head and neck reconstructions. ${ }^{22,23}$ Among other advantages, it is not necessary to move the patient when the flap is being prepared and elevated. In addition, it is possible to close the donor site directly by simply detaching the underlying tissues. The vascular pedicle is long and has a large diameter, which facilitates microvascular anastomosis with the recipient vessels. The superficial skin tissue that usually accompanies the muscle flap is often as good as that of any other donor site. The rich vascularization of the abdominal skin allows flexibility in the design of the skin paddle, making it easier for the surgeon to decide the thickness and design of the flap. ${ }^{23}$
There are some disadvantages in relation to the donor site. Occasionally, it may be necessary to transpose or change the place of insertion of the navel so that the abdominal wall is symmetrical. ${ }^{17}$ There is the risk that an abdominal hernia develops through wound dehiscence; to avoid dehiscence, the surgeon should remove the least amount possible of anterior rectus sheath and muscle and seek to preserve it below the arcuate line when elevating the flap. ${ }^{22}$ It was also mentioned that there will be weakness of the donor site in some cases, though it seems that the use of a synthetic mesh of equal size as that of the anterior sheath included in the flap could prevent the distortion of the remaining muscles of the abdominal wall. Direct approximation suture can also be performed. ${ }^{23}$ An exceptional case of the ileum has been published. ${ }^{22}$ Complications that can occur in the recipient site are related to the myocutaneous flap paddle, which in some patients may be too bulky. It is also possible that if the patient gains weight over time, the subcutaneous layer of fat tissue of the flap also increases, creating a contour that draws attention. ${ }^{17}$ Pilosity of the abdominal wall does not prevent the use of the skin paddle. Finally, systemic complications have also been observed, such as renal failure, mediastinitis, respiratory failure and disseminated intravascular coagulation. ${ }^{22}$

\section{CONCLUSION}

Fasciocutaneous radial forearm free flaps and myocutaneous rectus abdominis free flaps can be considered the most suitable flaps for reconstruction of cheek defects reaching the malar and temporal 
regions. This is because they allow the patient to maintain a supine position throughout the intervention while two teams, one preparing the recipienteptor site and the other designing the flap on the donor site, work. Both types of flap are performed quickly and easily, especially the radial flap, and they offer an excellent vascular pedicle that allows a rapid microvascular anastomosis with the recipient vessels. The selection of one or the other depends on the depth of the defect and the need for greater or smaller coverage. Another justificationreason for the use of myocutaneous rectus abdominis free flap is when the patient underwentthe employment of radiation therapy before treating the responsible tumor. ${ }^{23}$ The morbidity of the donor site is more evident aesthetically when the radial flap is used because forearm grafting is necessary. Since there is the possibility of abdominal hernia, the weakness and elevation of the abdominal wall should be avoided, making direct absorbable sutures in the muscle and subcutaneous tissue and silk sutures in the skin. The thickness of the flap is similar in both types, as the rectus abdominis flap also undergoes atrophy over time, producing an unaesthetic depression, similarly to the radial flap, even whenif thefat is stored. In each defect and each patient can use The rightA proper flap can be used for each defect and each patient. The choice of either depends on the size and depth of the defect, the patient's health and aesthetic aspirations of the patient.

\section{REFERENCES}

1. Bakamjian VY. The deltopeitoral flap. En: Grabb WC, Bert Myers MB, eds. Skin Flaps. Boston: Little, Brown and Co.Ed, B 1975;225-58.

2. Camacho FM. Backamjian flap. J Eur Acad Dermatol Venereol 2002; 16:532-48.

3. Camacho F. The trunk. In: Harahap M, ed. Skin Surgery. St.Louis: Warren H. Green Inc., 1985;499-633.

4. Mathes SJ. Muscle flaps and their blood supply. In: Aston SJ, Beasley RW, Thorne CHM, eds. Grabb and Smith's Plastic Surgery. Philadelphia; Lippincott-Raven Ed, 1997:61-71.

5. Morrison WA, O'Brien BMcC. Free flap transfer. In: Barron JN, Saad MN, eds Operative Plastic and Reconstructive Surgery. Edinburgh: Churchill Livingstone Ed, 1980;94-113.

6. De Bree R, Hartley C, Smeele LE, Kuik DJ, Quak JJ, Leemans R. Evaluation of donor site function and morbidity of the fasciocutaneous radial forearm flap. Laryngoscope 2004; 114:1973-6.

7. Prandl EC, Arbab E, Schintler MV, Koch H, Scharnagl E. Microcystic adnexal carcinoma in the nasolabial area: resection and reconstruction with a free Fasciocutaneous lateral arm flap with a sandwich technique. Dermatol Surg 2007; 33:378-81.

8. Richardson D. Fisher SE, Vaughan ED. Brown JS. Radial forearm flap donor-site complications and morbidity: a prospective study. Plast Reconstr Surg 1997; 99:109-15.

9. Brown MT, Couch ME, Huchton DM. Assessment of donor-site functional morbidity radial forearm fasciocutaneous free flaps harvest. Acta Otolaryngol Head Neck Surg 1999; 125:1371-4.

10. Skoner JM, Bascom DA, Cohen JI, Andersen PE, Wax MK. Short-term functional donor site morbidity after radial forearm fasciocutaneous free flap harvest. Laryngoscope 2003; 113:2091-4.

11. Toschka H, Feifel H, Erli HJ, Minkenberg R, Paar O, Riediger D. Aesthetic and functional results of harvesting radial forearm flap, especially with regard to hand function. Int J Oral Maxillofac Surg 2001; 30:42-8.

12. Suominen S, Ahovuo J, Asko-Seljavaara S. Donor site morbidity of radial forearm flaps: a clinical and ultrasonographic evaluation. Scand J Plast Reconstr Surg Hand Surg 1996; 30:57-61.

13. Moon HK, Taylor Gl. The vascular anatomy of rectus abdominis musculocutaneous flap based on the deep superior epigastric system. Plast Reconstr Surg1988; 82:815-32.

14. Tansatit T, Chokrungvaranont P, Sanguansit P, Wanidchaphloi S. Neurovascular anatomy of the deep inferior epigastric perforator flap for breast reconstruction. J Med Assoc Thai 2006; 89:1630-40.
15. El Mrakby HH, Milner RH. The vascular anatomy of the lower anterior abdominal wall: a microdissection study on the deep inferior epigastric vessels and the perforator branches. Plast Redconstr Surg 2002; 109:539-43.

16. Hasegawa K, Amagasa T, Araida T, Miyamoto H, Morita K. Oral and maxillofacial reconstruction using the free rectus abdominis myocutaneous flap. $\mathrm{J}$ Cranio Maxillofac Surg 1994; 22:236-43.

17. Piza-Katzar $\mathrm{H}$, Balogh B. Experience with 60 inferior rectus abdominis flaps. $\mathrm{Br} \mathrm{J}$ Plast Surg 1991; 44:438-43.

18. Allen RJ, Treece P. Deep inferior epigastric perforator flap for breast reconstruction Ann Plast Surg 1994; 32:32-8.

19. Vandevoort M, Vranckx JJ, Fabre G. Perforator topography of the deep inferior epigastric perforator flap in 100 cases of breast reconstruction. Plast Reconstr Surg 2002; 109:1912-8

20. Bohmert H, Strömbeck J0. Reconstrucção posmastectomía. En: Strömbeck J0, Rosato FE, eds. Cirurgia de a mama. Diagnóstico e tratamiento de las enfermedades de a mana. Barcelona: Salvat Ed, 1990; 250-73.

21. Izquierdo R, Leonetti JP, Origitano TC, Al-Mefty 0 , Anderson DE, Reichman $\mathrm{OH}$. Refinements using free-tissue transfer for complex cranial base reconstruction. Plast Reconstr Surg 1993; 92:567-75

22. Nakatsuka T, Harii K, Yamada A, Asato H, Ebihara S. Versatility of a free inferior rectus abdominis flap for head and neck reconstruction: Analysis of 200 cases. Plast Reconstr Surg 1994; 93:762-9.

23. Urken ML, Turk JB, Weinberg H, Vickery C, Biller HF. The rectus abdominis free flap in head and neck reconstruction. Arch Otolaryngol Head Neck Surg 1991; 117:857-66.

Como citar este artigo/How to cite this article: Camacho-Martínez FM, Rollón A, Salazar C, Rodríguez-Rey EM, Moreno D. Free flaps in Surgical Dermatology. Comparison between fasciocutaneous and myocutaneous free flaps in facial reconstructions. An Bras Dermatol. 2011;86(6):1145-50. 